\title{
New Advances in Juvenile Idiopathic Arthritis
}

\author{
Jing-Long Huang, MD
}

\begin{abstract}
Juvenile idiopathic arthritis (JIA) comprises a group of heterogeneous disorders of chronic arthritis in childhood with no apparent etiology. Juvenile idiopathic arthritis is the most common pediatric rheumatic disease and is associated with significant long-term morbidity and mortality. There have been major advances in recent years in our understanding of the pathogenesis of JIA, the definition of disease control, and biological treatments for JIA. Multiple environmental and genetic factors have been linked with the onset and / or the exacerbation of JIA, including perinatal factors, viral and bacterial infections, epigenetic factors, and malnutrition. However, no single causative factor has been identified to date. As our understanding of the complex network of immune cells and inflammatory cytokines has improved, biologics have been developed to modulate the inflammatory processes. Indeed, a

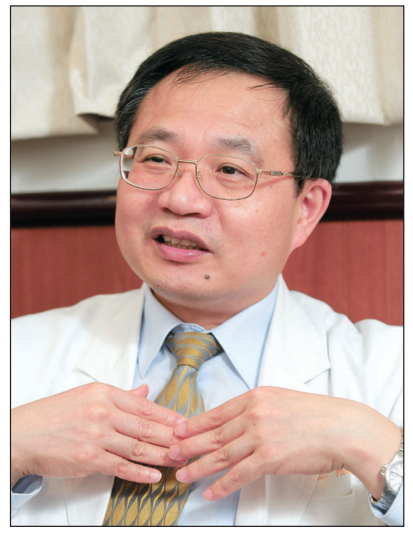

Prof. Jing-Long Huang number of such biologics have been demonstrated effective for the treatment of JIA. Although biologic agents may alleviate the inflammation associated with JIA and prevent disability caused by joint destruction, continued and comprehensive observation is required to determine the long-term outcomes associated with such treatment. (Chang Gung Med J $2012 ; 35: 1-14)$
\end{abstract}

Key words: juvenile idiopathic arthritis, etiology, biologic agents

$\mathbf{J}_{\mathrm{c}}^{\mathrm{u}}$ uvenile idiopathic arthritis (JIA) is a term that collectively refers to a group of chronic arthropathies, which together constitute the most common rheumatic condition in children. JIA is not a disease but an exclusion diagnosis that applies to any arthritis of unknown cause (such as infectious, oncologic, or other rheumatic etiologies) persisting for more than 6 weeks with an onset before the age of 16 years. ${ }^{(1,2)}$ According to the International League of Associations for Rheumatology, JIA consists of 8 heterogeneous subsets with unique clinical patterns of disease (Table 1) ${ }^{(3)}$ The aim of the new JIA classi- fication system was to define relatively homogeneous, mutually exclusive subsets of arthritis based on predominant clinical and laboratory features for both prognostic and research purposes. ${ }^{(4)}$ The term JIA has replaced previous nomenclature, including the terms "juvenile rheumatoid arthritis" used in the U.S.A. and "juvenile chronic arthritis" used in European countries. The original classification of JIA has been revised several times, most recently in 2004 , resulting in further clarification of the various subsets, correction of prior incongruence, and improvement in clinical utility to the rheumatolo-

From the Division of Allergy, Asthma and Rheumatology, Department of Pediatrics, Chang Gung Memorial Hospital at Linkou, Chang Gung University College of Medicine, Taoyuan, Taiwan.

Received: Apr. 13, 2011; Accepted: Aug. 12, 2011

Correspondence to: Prof. Jing-Long Huang, Division of Department of Pediatrics, Chang Gung Memorial Hospital at Linkou. 5, Fusing St., Gueishan Township, Taoyuan County 333, Taiwan (R.O.C.) Tel: 886-3-3281200 ext. 8206; Fax: 886-3-3294843;

E-mail: long@cgmh.org.tw 
Table 1. International League of Associations for Rheumatology Classification of Juvenile Iidiopathic Arthritis Subtypes and Clinical Features $^{(3)}$

\begin{tabular}{|c|c|}
\hline Oligoarthritis & Arthritis of 4 or fewer joints during the first 6 months \\
\hline Persistent & Affecting not more than 4 joints throughout the disease course \\
\hline Extended & Extending to affect more than 4 joints after the first 6 months \\
\hline Polyarthritis & Arthritis of 5 or more joints during the first 6 months \\
\hline RF positive & Subdivided according to presence of RF \\
\hline \multicolumn{2}{|l|}{ RF negative } \\
\hline \multirow[t]{5}{*}{ Systemic arthritis } & $\begin{array}{l}\text { Arthritis with or preceded by quotidian (daily) fever for at least } 3 \text { days, accompanied by one or more } \\
\text { of the following: }\end{array}$ \\
\hline & 1. Evanescent erythematous rash \\
\hline & 2. Lymphadenopathy \\
\hline & 3. Hepatomegaly and/or splenomegaly \\
\hline & 4. Serositis \\
\hline \multirow[t]{4}{*}{ Psoriatric arthritis } & Arthritis and psoriasis or arthritis and at least 2 of the following: \\
\hline & 1. Dactylitis \\
\hline & 2. Nail pitting or onycholysis \\
\hline & 3. Psoriasis in first-degree relative \\
\hline \multirow[t]{6}{*}{ Enthesitis-related arthritis } & Arthritis and enthesitis or arthritis or enthesitis with 2 of the following: \\
\hline & 1. Sacroiliac joint tenderness or inflammatory lumbosacral pain \\
\hline & 2. HLA-B27 antigen \\
\hline & 3. Onset of arthritis after age 6 years in males \\
\hline & 4. Acute (symptomatic) anterior uveitis \\
\hline & 5. History of HLA-B27-associated disease in a first-degree relative \\
\hline Undifferentiated arthritis & Arthritis that fulfils criteria in no category or more than 2 of the above categories \\
\hline
\end{tabular}

Adapted from Petty et al. ${ }^{(5)}$ and Brough and Cleary ${ }^{(104)}$

Abbreviations: RF: rheumatoid factor; HLA: human leukocyte antigen.

gist. ${ }^{(5)}$

Twenty years ago, it was commonly believed that JIA might subside in adulthood. Recent reports have shown that sustained resolution of articular disease occurs in only a small minority of JIA patients and that at least $50 \%$ of children with JIA enter adulthood with ongoing, active disease. ${ }^{(6,7)}$ The findings from these studies indicate that many patients diagnosed with JIA will have a prolonged disease course, require long term treatment, and likely be exposed to multiple medications. Fortunately, there have been significant advances in treatment over the last 2 decades that have led to improvements in the management of JIA. The major aims in the treatment of children with JIA are the following: 1) Recognize the specific challenges and obligations of a multidis- ciplinary team of specialized healthcare workers; and 2) Initiate early and aggressive treatment to not only control inflammation, but also switch off the disease process. ${ }^{(3,8)}$

\section{Epidemiology}

Approximately 1 in every 1000 children worldwide has JIA; however, the reported incidence and prevalence of JIA varies widely, in part because JIA is a heterogeneous disorder that is clinically identified and does not have a specific diagnostic test. Indeed, the available data are likely to underestimate the true incidence and prevalence of JIA because of underdiagnosis and because most studies are clinicbased rather than community-based. Prevalence rates ranging between 0.87 and $220 / 100,000$ have been 
reported in different population-based studies. ${ }^{(9)}$ According to a National Health Insurance database study, the prevalence of JIA in Taiwan is 3.7 / 100,000 , which is higher than the prevalence in Japan, but lower than the prevalence in most Caucasian populations. ${ }^{(10)}$

Overall, more females than males are affected by JIA; ${ }^{(11)}$ however, the sex distribution varies by disease subtype, with a striking female predominance in the oligoarticular and polyarticular onset subtypes, an even distribution of sexes in the systemic onset subtype, and a male predominance in the enthesitisrelated arthritis subtype. The age of onset also varies. The onset of oligoarthritis occurs at a median 5-years of age, followed by enthesitis related arthritis, and seropositive polyarthritis at a mean age of at least 8 to 9 years. Similar to most countries, the most common JIA subtype in Taiwan is oligoarthritis.

\section{The environment and JIA}

The majority of autoimmune diseases in adults and children are considered complex in etiology, with risk conferred by both genes and the environment. The incidence of some autoimmune diseases, such as type 1 diabetes, have significantly increased during the past several decades to an extent that cannot be explained by genetics alone. This suggests that environmental changes over the past several decades have likely contributed to the increased incidence of some autoimmune diseases. Unfortunately, little research has been undertaken to identify specific environmental risk factors for JIA. Indeed, only a handful of studies have been reported over the last two decades, the outcomes of which have not been replicated in independent populations. There are several barriers to JIA environmental risk factor research including: (1) the changing subtype classification systems, which can make comparison of studies published at different times difficult; (2) the low disease incidence, which limits prospective collection of pre-disease environmental data; and (3) the need to separately consider the different JIA subtypes, which further reduces the number of cases for comparison in studies with already small numbers. ${ }^{(12)}$

Early life events and the intrauterine environment have been epidemiologically associated with various diseases. ${ }^{(13)}$ In a 7-year cohort study, Jaakkola and Gissler reported that maternal smoking during pregnancy increased the risk of JIA in newborn
Finnish girls $(\mathrm{N}=58,841) .{ }^{(14)}$ Specifically, the authors reported that children born to mothers who smoked during pregnancy had a 2-fold higher rate of polyarthropathies than children born to mothers who did not smoke during pregnancy.

Breastfeeding has been reported to reduce the risk of developing JIA. Mason et al. performed a study to analyze the relationship between breastfeeding and the development of JIA and found that the odds ratio (OR) for JIA decreased with the duration of breastfeeding ( $0-3$ months: $\mathrm{OR}=0.56,95 \%$ confidence interval $[\mathrm{CI}]=0.23,1.14 ;>3$ months: $\mathrm{OR}=$ $0.28 ; 95 \% \mathrm{CI}=0.10,0.67) \cdot{ }^{(15)}$ However, Mason's study had a number of limitations, including low statistical power, selection bias, and the use of recall study methods. In a small scale study, Young et al. reported that children who were HLA-DR4 negative and breastfed for over 3 months were protected from developing JIA with rheumatoid factor positivity. ${ }^{(16)}$ Taken together, the available evidence suggests that there may be a relationship between breastfeeding and the development of JIA; however, this relationship has not been investigated in a large scale to date.

The relationship between various maternal, pregnancy, and birth characteristics, and early life infections and the risk of developing JIA was investigated in a register-based, case-control Swedish study that included 3,334 children with JIA and 13,336 control children. Birth after 42 weeks of gestation and birth by cesarean section were borderline associated with later onset JIA. ${ }^{(17)}$ Exposure to infection and other environmental factors at an older age increases the risk of developing an autoimmune disease. Infectious agents are believed to be the most important environmental factors leading to the development of autoimmunity. ${ }^{(18,19)}$

The role that infection plays in the initiation and augmentation of the symptoms of JIA is well established. Patients with JIA have been reported to have higher rates of infection with mycoplasma pneumonia, ${ }^{(20)}$ streptococcus, ${ }^{(21)}$ parvovirus B 19, ${ }^{(22)}$ and Epstein-Barr virus than children who do not have JIA. ${ }^{(23)}$ However, the mechanism through which infection increases the risk of JIA and other autoimmune diseases remains unclear. Molecular mimicry, whereby self-reactivity is triggered by cross-recognition of a self-peptide and an infectious peptide because of sequence similarity, has been reported. ${ }^{(12)}$ Infection may trigger activation of polyclonal lym- 
phocytes and increased immunogenicity of organs following infection-related inflammation. ${ }^{(24)}$ The onset of autoimmune diseases following vaccination has also been reported and various vaccines have been suggested to act as disease triggers. ${ }^{(25,26)}$ Vaccines may induce JIA through various mechanisms such as molecular mimicry (ie, where the vaccine acts as a self-antigen), antigen non-specific bystander activation, and polyclonal lymphocyte activation during the immune response to the vaccine. ${ }^{(18)}$

Case reports of JIA exacerbation following vaccination are rare. Only a single case of exacerbation of systemic JIA following rubella vaccination (a live-attenuated viral vaccine) has been described. ${ }^{(27)}$ The findings from epidemiologic studies suggest that there is no increased incidence or exacerbation of JIA shortly after vaccinations and that the introduction of new vaccines did not change the incidence of JIA. ${ }^{(28,29)}$ In a prospective study evaluating the effectiveness of hepatitis $B$ vaccination in children with JIA, no children were found to experience disease flare-up or clinical deterioration after vaccination. ${ }^{(30)}$ In another study, Borte et al. reported that there was no worsening of disease activity or any increase in medication use after children with JIA (being treated with anti-inflammatory medications including methotrexate and etanercept) received live-attenuated measles, mumps, and rubella vaccinations. ${ }^{(31)}$

Vitamin D plays an important role in modulating the human immune system. ${ }^{(32)}$ Indeed, $1,25(\mathrm{OH})_{2} \mathrm{D}_{3}$ is able to enhance the innate immune system. Further, $1,25(\mathrm{OH})_{2} \mathrm{D}_{3}$ has been shown to activate an antibacterial response by stimulating the production of antimicrobial peptides. ${ }^{\left({ }^{33}\right)}$ Furthermore, $1,25(\mathrm{OH})_{2} \mathrm{D}_{3}$ has also been demonstrated to influence the differentiation and maturation of dendritic cells in response to antigen presentation, and downregulate the expression of cytokines, such as interleukin (IL)-12, that are associated with $\mathrm{T}$ helper (Th) 1 cells. $^{(34)}$ Th 1 cells are known to mediate the autoimmune response in JIA. The newly described Th cell, Th17, which produces the proinflammatory cytokine IL-17, is thought to play a role in the pathogenesis of autoimmune diseases, including JIA. ${ }^{(35)}$ There is evidence to suggest that $1,25(\mathrm{OH})_{2} \mathrm{D}_{3}$ inhibits the secretion of Th17 cells via a number of pathways, including reduction of the expression of the Th17 stimulatory factor IL-6. ${ }^{(36-38)}$ These study findings support the theory that vitamin D plays a role in the pathophysiology of JIA.

Although the findings from many studies and various immune mechanisms highlight the association between JIA and the environment, the causal relationship between JIA and environmental factors is obscure and requires more comprehensive investigation. Multiple environmental factors have been reported to induce or exacerbate JIA, however, no single causative factor has been identified thus far. ${ }^{(18)}$

\section{The genetics of JIA}

Several genetic loci have been proposed to be associated with susceptibility to JIA and the severity of JIA. A number of well documented and replicated associations between human leukocyte antigens (HLA) and JIA have been reported. These associations vary between JIA subtypes. For HLA class I alleles, HLA-A2 has been shown to be associated with JIA, particularly in children with an early disease onset. HLA-B27 has long been associated with the development of enthesitis -related arthritis in both adults and children. For HLA class II alleles, increased frequencies of HLA-DRB $1 * 08,11$ and 13 and DPB $1 * 02$ have been reported in Caucasian children with JIA, while an increased frequency of HLADRB $1 * 0405$ has been reported in Asian children with JIA. ${ }^{(39)}$ Although many different non-HLA candidate loci have been investigated for associations with JIA and JIA subtypes, very few have been identified. Prahalad and Glass reported that although over 100 different candidate genes have been studied in over 150 association-based studies of JIA, ${ }^{(40)}$ only a handful (MIF, NRAMP1, PTPN22, TNFA, and WISP3) have shown replication. Prahalad et al. reported strong associations between the TNFAIP3 variant and oligoarticular JIA and the STAT4 variant and polyarticular JIA. ${ }^{(41)}$

\section{Pathogenesis}

Juvenile idiopathic arthritis encompasses a heterogeneous group of diseases characterized by chronic inflammatory processes involving the synovial membrane, cartilage, and bone. ${ }^{(1)}$ The classification of JIA subgroups are based on clinical and laboratory characteristics including the number of affected joints and the presence of autoimmune markers. The histopathological hallmark of JIA is infiltration of the synovium by lymphocytes, plasma 
cells, macrophages, and dendritic cells. ${ }^{(42)}$ The proliferation of fibroblast- and macrophage-like synoviocytes is another prominent feature of the inflamed synovium in JIA. Histologically, systemic JIA (sJIA) is subsumed under the term JIA. However, from a pathophysiological point of view, sJIA may be better categorized as an autoinflammatory syndrome. Children with sJIA do not exhibit signs of lymphocyte-mediated, antigen-specific immune reactions. Rather, the typical clinical signs of sJIA are associated with granulocytosis, thrombocytosis, and upregulation of acute phase reactants, indicating uncontrolled activation of the innate immune system. ${ }^{(43)}$ In our previous study, increased expression of leukocyte adhesion molecules such as E-selectin, vascular cell adhesion molecule-1, and intercellular adhesion molecule-1 were shown in patients in both the active and remission stages of JIA. ${ }^{(44)}$ Subsequent recruitment of perivascular neutrophil infiltrates and proinflammatory activation of monocytes have also been reported. ${ }^{(45)}$

Juvenile idiopathic arthritis has been suggested to be a Th1 cell-mediated disorder, driven by a population of $\mathrm{T}$ cells producing inflammatory cytokines and chemokines. ${ }^{(46)}$ Cytokines are directly implicated in many of the immune processes that are associated with the pathogenesis of JIA. Numerous cytokines are secreted and are functionally active in synovial tissues. The most important proinflammatory cytokines produced by phagocytes are tumor necrosis factor- $\alpha$ (TNF- $\alpha$ ), IL-1, and IL-6. These cytokines play roles in specific immunological processes that promote autoimmunity, chronic inflammation, and tissue destruction. ${ }^{(47)}$ Expression levels of TNF- $\alpha$, IL-1 $\beta$, and IL- 6 appear to be highest in patients with sJIA compared with patients with polyarticular or pauci-JIA, ${ }^{(48)}$ and correlate with the severity of JIA disease and joint destruction.

Heat shock proteins (HSPs), proteins produced in response to stress, are also potential autoantigens in JIA. Circulating T cells from JIA patients, but not control individuals, react to human HSP60. ${ }^{(49,50)}$ Human HSP is also expressed on the synovial membrane in patients with JIA, potentially acting as an autoantigen. ${ }^{(51)} \mathrm{Wu}$ et al. reported that serum concentrations of Hsp60 in patients with active and inactive oligoarticular and polyarticular JIA were significantly higher than in normal control individuals. ${ }^{(52)}$ Serum concentrations of anti-Hsp60 were $49.25 \mathrm{ng} / \mathrm{mL}$ in patients with active oligoarticular JIA and 35.76 $\mathrm{ng} / \mathrm{mL}$ in control individuals $(p=0.059)$. Serum concentrations of anti-Hsp60 were $65.05 \mathrm{ng} / \mathrm{mL}$ in patients with polyarticular JIA ( $p=0.008$ vs control). Further, serum concentrations of Hsp60 correlated with the time from remission to flare-up in patients with JIA. ${ }^{(52)}$

Synovial fluid samples from patients with different JIA subtypes show markedly different CD4 / CD8 ratios, ${ }^{(53)}$ proportions of activated CD4 and CD8 $\mathrm{T}$ cells, ${ }^{(53)}$ degrees of clonal expansion, ${ }^{(54)}$ associated HLA-DR B1 loci, and involvement of $\mathrm{V} \beta$ families among the highly oligoclonally expanded $\mathrm{T}$ cells. ${ }^{(55)}$ These findings suggest that different autoantigens may be involved in different JIA subtypes. Yao et al. reported mutation of the RANTES gene promoter in patients with JIA and this mutation was associated with increased RANTES secretion and synovial membrane inflammation. ${ }^{(56)}$ Persistently abnormal serum levels of RANTES in the remission stage of JIA may be an important predictor of disease flareup within 6 months. ${ }^{(57)}$ Antigen-driven T cells play a central role in the pathogenesis of JIA, ${ }^{(42)}$ including the predominance of $\mathrm{T}$ lymphocytes in the synovial infiltrate, and the activated phenotypes of the infiltrating CD4 and CD8 T cells as indicated by expression of CD25 (IL-2R), CD45RO, CD69, very late activation antigen type 1 , MHC class II and several activation-dependent chemokine receptors such as CCR5, RANTES and CXCR3. ${ }^{(53,58-60)}$

Recently, studies in animals using a model of collagen-induced arthritis (CIA) have implicated IL17 producing $\mathrm{T}$ cells in the pathogenesis of autoimmune disease. ${ }^{(61)}$ The inflamed joints in patients with JIA are enriched with IL-17-producing T cells and high levels of IL-17, in excess of serum levels, have been detected in synovial fluid from patients with polyarticular JIA. ${ }^{(35,62)}$ Interleukin-17 may induce synoviocyte production of IL-6, matrix metalloproteinases 1 and 3, and IL-8 (which is chemotactic for neutrophils), all of which have been implicated in the joint destruction process. ${ }^{(62)}$ Further, it has been reported that mice lacking expression of Th1-cell associated genes, including interferon (IFN)- $\gamma$, IFN$\gamma \mathrm{R}$, and IL-12 p35, can develop CIA. ${ }^{(63-65)}$ In contrast, and consistent with Th17 cells playing a role in mediating arthritic disease, IL-6-/- mice and IL-23 p19-/ mice do not develop CIA, and inhibition or overexpression of IL-17 in the joint suppresses or 
worsens joint inflammation and damage, respectively. ${ }^{(61)}$ The findings from these studies suggest that Th17 cells can be induced by IL- 6 and IL-23 and thus act as the key effector-cell subset in inflammatory arthritis. An excess of Th17 cells has been detected in the joints of adults with rheumatoid arthritis ${ }^{(66,67)}$ and in children with JIA, particularly in those individuals with more advanced disease. ${ }^{(68)}$ Weaver et al. reported that IL-17 drives neutrophil differentiation, maturation, activation, cytokine release, monocyte activation, and synovial fibroblast activation, chemokine release, prostaglandin production and matrix metalloproteinase synthesis. ${ }^{(69)}$ A synergistic interaction between IL-17, IL-1 $\beta$, and TNF- $\alpha$, leading to synovial fibroblast activation and cytokine secretion, suggests that IL-17 plays a role in the pathogenesis of joint destruction. ${ }^{(61,70)}$

Recent investigations have focused on mediators of the innate immune system in JIA. Serum concentrations of the calcium-binding proteins S100A8, S100A9, and S100A12, which are produced from activated neutrophils and monocytes, are increased in oligoarticular and polyarticular JIA and correlate with the severity of joint inflammation. ${ }^{(71)}$ S100A12 has proinflammatory properties in vitro at concentrations found in sJIA serum in vivo ${ }^{(72,73)}$ and is highly expressed in patients with sJIA. ${ }^{(74)}$ These molecules are damage-associated molecular pattern proteins, which act as endogenous danger signals and activate immune cells and the vascular endothelium. ${ }^{(75)}$ Protein S100A12 seems to be a member of a novel inflammatory signaling pathway involving the receptor for advanced glycation end products which transduce proinflammatory signals in endothelial cells and phagocytes. ${ }^{(75,76)}$ Protein S100A12 may induce the expression of adhesion molecules as well as proinflammatory cytokines on endothelial cells in a nuclear factor- $\kappa \mathrm{B}$-dependent manner. Proteins S100A8 / S100A9 and S100A12 act early in the inflammatory cascade associated with periods of disease activity. ${ }^{(72,77)}$ The early phases of a clinical trial examining the importance of S100A8 / S100A9 and S100A12 in chronic arthritis has been completed with positive results. The specific overexpression of IL-1, IL-18, S100A8, S100A9, and S100A12 may play a novel role in the pathogenesis of sJIA. All of these molecules are secreted by a so- called alternative pathway, which is different from the classic intracellular transport mechanism involving the endothelium and Golgi complex. The initial activation of IL-1 and IL-18 involves a proteolytic cleavage of inactiveprocytokines by a multiprotein complex called an inflammasome. The uncontrolled activation of inflammasomes and cleavage of pro-IL-1 by caspase- 1 have been suggested to be important molecular mechanisms in systemic JIA. ${ }^{(45,78,79)}$

\section{Advances in the treatment of JIA \\ Standardized measures of clinical outcomes}

The goals in treating JIA are to eliminate active disease, normalize joint function, preserve normal growth, prevent long-term joint damage, and prevent patient disability.

The American College of Rheumatology Pediatric 30 criteria (ACR Pedi 30) defines improvement as involving at least 3 of 6 core set variables, with no more than 1 of the remaining variables worsening by $>30 \%$. The 6 core set includes physician global assessment, active joint count, number of joints with limited range of motion, inflammatory markers, and patient or parent assessments. These measures of global and specific health-related outcomes have been developed and refined to evaluate JIA while keeping pace with the development of new therapies. ${ }^{(3)}$ Important steps have occurred in the optimization of treatment for JIA.

\section{Intra-articular injection of corticosteroids}

Intra-articular corticosteroid injections are used early in the disease course, ${ }^{(80,81)}$ and can be a rapid and long-lasting effective therapy used solely or in combination with other systemic treatments. Patients with JIA who were treated with intra-articular triamcinolone hexacetonide $(\mathrm{TH})$ had significantly higher response rates at 6 months compared with patients who were treated with triamcinolone acetonide (TA) $(81.4 \%$ vs $53.3 \%, p=0.001) .{ }^{(82)}$ Similarly, patients treated with $\mathrm{TH}$ had a longer time to relapse than patients treated with TA (10.14 vs 7.75 months, $p<$ 0.001). ${ }^{(81)}$ These findings suggest that $\mathrm{TH}$ offers a significant advantage over TA in the treatment of large inflamed joints in JIA, particularly for patients with oligoarticular JIA.

\section{Biologic agents}

Advances in our understanding of the immune system have revealed details of the pathways involved in inflammation and self-tolerance and have 
led to the development of new medications for treatment of JIA. A major advance in the management of JIA has been the advent of biological therapies developed to target specific mediators of the inflammatory response. Biologic agents are genetically engineered drugs designed to selectively block the effects of cytokines implicated in JIA, including TNF- $\alpha$, IL-1, and IL- 6 , as well as signaling molecules involved in the regulation of B-cell and T-cell lymphocyte responses (Table 2). ${ }^{(6)}$

\section{TNF- $\alpha$ Antagonists}

TNF- $\alpha$ is a potent proinflammatory cytokine. Elevated serum and synovial fluid TNF- $\alpha$ concentrations have been detected in patients with JIA. Three biologic agents targeting TNF- $\alpha$ (etanercept, infliximab, and adalimumab) are currently being used to treat JIA.

\section{Etanercept}

The first multicenter, double-blind randomized controlled trial of biologic therapy (etanercept) for JIA was undertaken in 51 patients (aged 4 to 17 years) with refractory polyarticular JIA. ${ }^{(83)}$ Patients treated with etanercept were found to have signifi- cantly lower rates of disease flare-up in the subsequent 4-month period than patients treated with a placebo ( $28 \%$ vs $81 \%, p=0.003)$. Radiographic progression of joint damage was also reduced following treatment with etanercept in children with JIA. ${ }^{(84)}$ Billiau et al. further reported that etanercept improved linear growth and bone mass after 18 months of treatment in 16 children with methotrexate (MTX)-resistant polyarticular JIA. ${ }^{(85)}$

Etanercept treatment is associated with satisfactory short- and long-term safety and tolerability. The Dutch National Register reported that $77 \%$ of patients with JIA $(\mathrm{N}=146)$ met ACR Pedi30 criteria in the initial 3 months of treatment with etanercept (median follow-up $=2.5$ years $/$ patient; range $=0.3$ to 7.3 years). ${ }^{(86)}$ For the majority of patients, this improvement was sustained, with $36 \%$ of patients meeting remission criteria. Lovell et al. performed an 8 -year clinical trial of etanercept demonstrating the long-term safety and efficacy of this treatment. ${ }^{(87)}$ Mild adverse events including injection site reactions, upper respiratory tract infection, and headache were reported at a rate of 0.15 to 0.21 events per patient-year of exposure, while serious adverse events such as bacterial infection and hospitalization

Table 2. Biologic Therapeutics in Use or in Development for Treatment of Juvenile Idiopathic Arthritis

\begin{tabular}{|c|c|c|}
\hline Drug & Action & Dose \\
\hline Etanercept & $\begin{array}{l}\text { Soluble TNF } \mathrm{p} 75 \text { receptor fusion protein that binds to and } \\
\text { inactivates TNF } \alpha\end{array}$ & $\begin{array}{l}0.4 \mathrm{mg} / \mathrm{kg} \text { twice weekly; } \\
0.8 \mathrm{mg} / \mathrm{kg} / \text { week; maximum } 50 \mathrm{mg} / \text { dose; } \mathrm{SC}\end{array}$ \\
\hline Infliximab & $\begin{array}{l}\text { Chimeric human/mouse monoclonal antibody that binds to soluble } \\
\text { TNF } \alpha \text { and its membrane- bound precursor, neutralizing its action }\end{array}$ & $\begin{array}{l}6 \text { to } 10 \mathrm{mg} / \mathrm{kg} / \mathrm{dose} \text { weeks } 0,2 \text { and } 6 \text {; } \\
\text { then every } 4 \text { to } 8 \text { weeks; IV }\end{array}$ \\
\hline Adalimumab & A human immunoglobulin G1 monoclonal antibody which binds to TNF $\alpha$ & $\begin{array}{l}24 \mathrm{mg} / \mathrm{m}^{2} \text { every } 2 \text { weeks; maximum } \\
40 \mathrm{mg} / \text { dose; } \mathrm{SC}\end{array}$ \\
\hline Abatacept & $\begin{array}{l}\text { Soluble human fusion protein of the extracellular domain of cytotoxic } \\
\text { T-lymphocyte-associated antigen- } 4 \text {, linked to a modified Fc portion of } \\
\text { human immunoglobulin G1. A co-stimulatory signal inhibitor that binds } \\
\text { competitively to CD } 80 \text { or CD86, where it selectively inhibits T-cell activation }\end{array}$ & $\begin{array}{l}10 \mathrm{mg} / \mathrm{kg} \text { weeks } 0,2 \text { and } 4 \text {; then every } \\
4 \text { weeks, maximum } 1,000 \mathrm{mg} / \text { dose; IV }\end{array}$ \\
\hline Anakinra & An interleukin-1 receptor antagonist & $\begin{array}{l}1 \text { to } 2 \mathrm{mg} / \mathrm{kg} / \mathrm{day} \text {, maximum } 100 \\
\mathrm{mg} / \mathrm{dose} ; \mathrm{SC}\end{array}$ \\
\hline Rituximab & $\begin{array}{l}\text { Chimeric monoclonal antibody that binds to cell surface CD20 receptor of } \\
\text { mature B cells }\end{array}$ & $\begin{array}{l}750 \mathrm{mg} / \mathrm{m}^{2} ; \text { two doses } 2 \text { weeks apart or } \\
375 \mathrm{mg} / \mathrm{m}^{2} ; 4 \text { doses, weekly x } 4 \text {, maximum } \\
1,000 \mathrm{mg} / \text { dose; IV }\end{array}$ \\
\hline Tocilizumab & A humanised anti-human interleukin-6 receptor monoclonal antibody & 8 to $12 \mathrm{mg} / \mathrm{kg}$ every 2 weeks; IV \\
\hline
\end{tabular}

Adapted from Strand et al. ${ }^{(105)}$

Abbreviations: IV: intravenous; SC: subcutaneous; TNF: tumor necrosis factor; Fc: fragment,crystallizable; CD: cluster of differentiation. 
occurred at rates ranging from 0.029 to 0.10 events per patient-year of exposure..$^{(5)}$

\section{Infliximab}

Unlike etanercept, infliximab binds both soluble and membrane-bound TNF- $\alpha$. A 14 week international, multicenter, randomized controlled trial of infliximab in patients with polyarticular JIA refractory to MTX $(\mathrm{N}=122)$ revealed that a higher proportion of patients treated with infliximab met ACR Pedi 30 criteria than those treated with a placebo; however, the between group difference was not significant. ${ }^{(88)}$ Patients treated with infliximab may experience mild infusion-related symptoms such as rash, headache, and severe anaphylactic reaction. These adverse events are possibly related to immune responses against the mostly humanized mouse monoclonal antibody. ${ }^{(89)}$

\section{Adalimumab}

Adalimumab is a fully humanized monoclonal antibody that binds soluble and membrane-bound TNF- $\alpha$. Lovell et al. reported the results of a phase III randomized, double-blinded, placebo-controlled trial in which 171 patients with polyarticular JIA were treated with adalimumab for 16 weeks. All patients were either MTX naïve or had exhibited an inadequate response to MTX. ${ }^{(90)}$ After 16 weeks of treatment, $74 \%$ of patients not receiving MTX and 94\% of those receiving MTX met ACR Pedi 30 criteria. Of the patients receiving MTX, there was a significant increase in the number of disease flareups in those patients who subsequently received a placebo vs adalimumab $(71 \%$ vs $43 \%, p=0.03)$.

It is thought that the 3 TNF- $\alpha$ antagonists will have similar long-term side effects. Postmarketing surveillance studies have demonstrated increased risks of sepsis, opportunistic infections, tuberculosis, demyelinating diseases, and lupus-like reactions. Severe infections have been reported at a rate of 0.01 to 0.02 events per patient-year of exposure. The development of novel autoantibodies including antinuclear antibodies was also noted in $16 \%$ of patients after anti-TNF- $\alpha$ therapy. ${ }^{(84)}$

\section{IL-1 antagonists}

Anakinra is a recombinant form of the human IL-1 receptor antagonist that competitively binds the IL-1 receptor and thus blocks endogenous IL-1 sig- naling. In uncontrolled studies in patients with refractory sJIA who were resistant to MTX and TNF- $\alpha$ antagonists, treatment with anakinra led to rapid (within days) and sustained remission. ${ }^{(50,91-93)}$ However, recent reports suggest that not all patients with sJIA respond to treatment with anti-IL-1 and that the response is not always sustained. ${ }^{(94,95)}$ These findings suggest there may be two distinct phenotypes of sJIA; one which is responsive, and the other which is non- or less responsive to IL-1 blockade. ${ }^{(96)}$ Local injection site reactions and injection pain are frequent side effects of anakinra treatment. Infection and anaphylaxis have also been reported. ${ }^{(94)}$

Rilonacept (IL-1 Trap) is another IL-1 blocking agent currently undergoing trials in children with sJIA. Rilonacept is a recombinant fusion protein that combines IL-1 receptor protein components with the Fc portion of human IgG1. Rilonacept comprises extracellular domains of both receptor components required for IL-1 signaling ie, the IL-1 type 1 receptor and IL-1 receptor accessory protein. Rilonacept might be a more efficient inhibitor of in vivo IL-1 signaling than anakinra. Recently, rilonacept was proven effective in a phase II trial of familial cold autoinflammatory syndrome, which is similar to sJIA. ${ }^{(97)}$ A double-blinded, placebo-controlled study of rilonacept in children with sJIA, followed by an open-label extension trial is in progress.

\begin{abstract}
Abatacept
Abatacept is a recombinant fusion protein with a unique mechanism of action. Abatacept comprises the Fc portion of the human immunoglobulin molecule combined with the extracellular portion of cytotoxic T-lymphocyte-associated antigen $4 .{ }^{(98)}$ Abatacept acts by preventing the generation of a costimulatory signal required for T-cell activation. Abatacept thus downregulates T-cell stimulation, leading to decreased B-cell and macrophage activation, and also modulates multiple downstream inflammatory cytokine pathways that have been implicated in the pathogenesis of JIA. ${ }^{(6)}$ The results of a double-blind, randomized controlled withdrawal trial of abatacept in 190 patients with JIA and poor responses to disease-modifying antirheumatic drugs (DMARD), including anti-TNF therapy, have been reported. ${ }^{(99)}$ After 4 months of treatment with abatacept, $65 \%$ of patients met ACR Pedi 30 criteria. More specifically, ACR Pedi 50, Pedi 70, and Pedi
\end{abstract}


90 response rates were $50 \%, 28 \%$, and $13 \%$, respectively. No serious or opportunistic infections were reported.

\section{Rituximab}

Rituximab is a chimeric monoclonal antibody to CD20, a cell surface marker found on mature B cells. Binding of the monoclonal antibody to CD20 results in selective depletion of CD20-positive B cells. ${ }^{(100)}$ Although, rituximab has been shown effective in the treatment of adult rheumatoid arthritis, there are only rare reports of rituximab treatment in children with severe refractory JIA. ${ }^{(101,102)}$

\section{Tocilizumab}

Tocilizumab is a recombinant, humanized monoclonal antibody that binds to the IL- 6 receptor and blocks downstream signaling of IL-6. Yokota and colleagues have reported the results of a phase III trial in which 56 children with sJIA who did not respond to DMARDs were treated with tocilizumab $(8 \mathrm{mg} / \mathrm{kg})$ for 12 weeks. ${ }^{(103)}$ The authors reported that ACR Pedi 30, 50, and 70 criteria were met in $91 \%$, $86 \%$, and $68 \%$ of patients, respectively. A total of $80 \%$ of patients treated with tocilizumab maintained an ACR Pedi 30 response or better, compared with only $17 \%$ of patients who received a placebo.

It remains to be determined whether tocilizumab can outperform etanercept in a head to head comparison.

\section{Summary \\ New definitions of inactive disease and clinical remission and increased understanding of the patho- genesis of JIA have facilitated the development of biologics and improved JIA treatment options. New insights into the complex network of immune cells and inflammatory cytokines have led to the develop- ment of drugs that target these mechanisms with proven effectiveness in the treatment of JIA. New biological agents are continually being developed to treat JIA. Performing clinical trials to prove the qual- ity, safety, and efficacy of these biologics remains an ongoing challenge. Accumulating evidence suggests that early disease control may be important in deter- mining long-term outcomes in patients with JIA. Although newer biologic agents may alleviate inflammatory arthritis and prevent the disability associated with joint destruction, continued and com-}

prehensive observation is required to determine the long-term outcomes associated with these treatments.

\section{REFERENCES}

1. Ravelli A, Martini A. Juvenile idiopathic arthritis. Lancet 2007;369:767-78.

2. Cassidy JT, Levinson JE, Bass JC, Baum J, Brewer EJ Jr., Fink CW, Hanson V, Jacobs JC, Masi AT, Schaller JG, Fries JF, McShane D, Young D. A study of classification criteria for a diagnosis of juvenile rheumatoid arthritis. Arthritis Rheum 1986;29:274-81.

3. Beresford MW, Baildam EM. New advances in the management of juvenile idiopathic arthritis--1: non-biological therapy. Arch Dis Child Educ Pract Ed 2009;94:144-50.

4. Kahn P. Juvenile idiopathic arthritis--current and future therapies. Bull NYU Hosp Jt Dis 2009;67:291-302.

5. Petty RE, Southwood TR, Manners P, Baum J, Glass DN, Goldenberg J, He X, Maldonado-Cocco J, Orozco-Alcala J, Prieur AM, Suarez-Almazor ME, Woo P. International League of Associations for Rheumatology classification of juvenile idiopathic arthritis: second revision, Edmonton, 2001. J Rheumatol 2004;31:390-2.

6. Hayward K, Wallace CA. Recent developments in antirheumatic drugs in pediatrics: treatment of juvenile idiopathic arthritis. Arthritis Res Ther 2009;11:216.

7. Minden K, Kiessling U, Listing J, Niewerth M, Doring E, Meincke J, Schontube M, Zink A. Prognosis of patients with juvenile chronic arthritis and juvenile spondyloarthropathy. J Rheumatol 2000;27:2256-63.

8. Baildam E, Davidson J. BSPAR position statement on professionals working in paediatric rheumatology. Rheumatology 2008;47:743-4.

9. Oen KG, Cheang M. Epidemiology of chronic arthritis in childhood. Semin Arthritis Rheum 1996;26:575-91.

10. Huang JL, Yao TC, See LC. Prevalence of pediatric systemic lupus erythematosus and juvenile chronic arthritis in a Chinese population: a nation-wide prospective population-based study in Taiwan. Clin Exp Rheumatol 2004;22:776-80.

11. Martini A, Lovell DJ. Juvenile idiopathic arthritis: state of the art and future perspectives. Ann Rheum Dis 2010;69: 1260-3.

12. Ellis JA, Munro JE, Ponsonby AL. Possible environmental determinants of juvenile idiopathic arthritis. Rheumatology 2010;49:411-25.

13. Simmons RA. Developmental origins of adult disease. Pediatr Clin North Am 2009;56:449-66.

14. Jaakkola JJ, Gissler M. Maternal smoking in pregnancy as a determinant of rheumatoid arthritis and other inflammatory polyarthropathies during the first 7 years of life. Int $\mathrm{J}$ Epidemiol 2005;34:664-71.

15. Mason T, Rabinovich CE, Fredrickson DD, Amoroso K, Reed AM, Stein LD, Kredich DW. Breast feeding and the 
development of juvenile rheumatoid arthritis. J Rheumatol 1995;22:1166-70.

16. Young KA, Parrish LA, Zerbe GO, Rewers M, Deane KD, Michael Holers V, Norris JM. Perinatal and early childhood risk factors associated with rheumatoid factor positivity in a healthy paediatric population. Ann Rheum Dis 2007;66:179-83.

17. Carlens C, Jacobsson L, Brandt L, Cnattingius S, Stephansson O, Askling J. Perinatal characteristics, early life infections and later risk of rheumatoid arthritis and juvenile idiopathic arthritis. Ann Rheum Dis 2009;68: 1159-64.

18. Berkun Y, Padeh S. Environmental factors and the geoepidemiology of juvenile idiopathic arthritis. Autoimmun Rev 2010;9:A319-24.

19. Zandman-Goddard G, Berkun Y, Barzilai O, Boaz M, Blank M, Ram M, Sherer Y, Anaya JM, Shoenfeld Y. Exposure to Epstein-Barr virus infection is associated with mild systemic lupus erythematosus disease. Ann N Y Acad Sci 2009;1173:658-63.

20. Oen K, Fast M, Postl B. Epidemiology of juvenile rheumatoid arthritis in Manitoba, Canada, 1975-92: cycles in incidence. J Rheumatol 1995;22:745-50.

21. Barash J, Goldzweig O. Possible role of streptococcal infection in flares of juvenile idiopathic arthritis. Arthritis Rheum 2007;57:877-80.

22. Oguz F, Akdeniz C, Unuvar E, Kucukbasmaci O, Sidal M. Parvovirus B19 in the acute arthropathies and juvenile rheumatoid arthritis. J Paediatr Child Health 2002;38:35862.

23. Massa M, Mazzoli F, Pignatti P, De Benedetti F, Passalia M, Viola S, Samodal R, La Cava A, Giannoni F, Ollier W, Martini A, Albani S. Proinflammatory responses to self HLA epitopes are triggered by molecular mimicry to Epstein-Barr virus proteins in oligoarticular juvenile idiopathic arthritis. Arthritis Rheum 2002;46:2721-9.

24. Bach JF. Infections and autoimmune diseases. J Autoimmun 2005;25 Suppl:74-80.

25. Tishler M, Shoenfeld Y. Vaccination may be associated with autoimmune diseases. Isr Med Assoc J 2004;6:4302.

26. Berkun Y, Mimouni D, Shoenfeld Y. Pemphigus following hepatitis B vaccination--coincidence or causality? Autoimmunity 2005;38:117-9.

27. Korematsu S, Miyahara H, Kawano T, Yamada H, Akiyoshi K, Sato K, Maeda T, Suenobu S, Izumi T. A relapse of systemic type juvenile idiopathic arthritis after a rubella vaccination in a patient during a long-term remission period. Vaccine 2009;27:5041-2.

28. Kanakoudi-Tsakalidou F, Trachana M, Pratsidou-Gertsi P, Tsitsami E, Kyriazopoulou-Dalaina V. Influenza vaccination in children with chronic rheumatic diseases and longterm immunosuppressive therapy. Clin Exp Rheumatol 2001;19:589-94.

29. Malleson PN, Tekano JL, Scheifele DW, Weber JM.
Influenza immunization in children with chronic arthritis: a prospective study. J Rheumatol 1993;20:1769-73.

30. Kasapcopur O, Cullu F, Kamburoglu-Goksel A, Cam H, Akdenizli E, Calykan S, Sever L, Arysoy N. Hepatitis B vaccination in children with juvenile idiopathic arthritis. Ann Rheum Dis 2004;63:1128-30.

31. Borte S, Liebert UG, Borte M, Sack U. Efficacy of measles, mumps and rubella revaccination in children with juvenile idiopathic arthritis treated with methotrexate and etanercept. Rheumatology 2009;48:144-8.

32. Ponsonby AL, Lucas RM, van der Mei IA. UVR, vitamin $\mathrm{D}$ and three autoimmune diseases--multiple sclerosis, type 1 diabetes, rheumatoid arthritis. Photochem Photobiol 2005;81:1267-75.

33. Liu PT, Stenger S, Li H, Wenzel L, Tan BH, Krutzik SR, Ochoa MT, Schauber J, Wu K, Meinken C, Kamen DL, Wagner M, Bals R, Steinmeyer A, Zugel U, Gallo RL, Eisenberg D, Hewison M, Hollis BW, Adams JS, Bloom BR, Modlin RL. Toll-like receptor triggering of a vitamin $\mathrm{D}$-mediated human antimicrobial response. Science 2006;311:1770-3.

34. Penna G, Adorini L. 1 Alpha, 25-dihydroxyvitamin D3 inhibits differentiation, maturation, activation, and survival of dendritic cells leading to impaired alloreactive $\mathrm{T}$ cell activation. J Immunol 2000;164:2405-11.

35. Nistala K, Moncrieffe H, Newton KR, Varsani H, Hunter $\mathrm{P}$, Wedderburn LR. Interleukin-17-producing $\mathrm{T}$ cells are enriched in the joints of children with arthritis, but have a reciprocal relationship to regulatory $\mathrm{T}$ cell numbers. Arthritis Rheum 2008;58:875-87.

36. Arnson Y, Amital H, Shoenfeld Y. Vitamin D and autoimmunity: new aetiological and therapeutic considerations. Ann Rheum Dis 2007;66:1137-42.

37. Fujimoto M, Serada S, Mihara M, Uchiyama Y, Yoshida H, Koike N, Ohsugi Y, Nishikawa T, Ripley B, Kimura A, Kishimoto T, Naka T. Interleukin-6 blockade suppresses autoimmune arthritis in mice by the inhibition of inflammatory Th17 responses. Arthritis Rheum 2008;58:3710-9.

38. Mihara M, Ohsugi Y, Kishimoto T. Evidence for the role of Th17 cell inhibition in the prevention of autoimmune diseases by anti-interluekin-6 receptor antibody. Biofactors 2009;35:47-51.

39. Huang JL, Yeh CC, Shaw CK, Yao TC, Chen LC, Lee TD, Kuo ML. HLA-DRB1 genotyping in patients with juvenile idiopathic arthritis in Taiwan. Eur J Immunogenet 2004;31:185-8.

40. Prahalad S, Glass DN. A comprehensive review of the genetics of juvenile idiopathic arthritis. Pediatr Rheumatol Online J 2008;6:11.

41. Prahalad S, Hansen S, Whiting A, Guthery SL, Clifford B, McNally B, Zeft AS, Bohnsack JF, Jorde LB. Variants in TNFAIP3, STAT4, and C12orf30 loci associated with multiple autoimmune diseases are also associated with juvenile idiopathic arthritis. Arthritis Rheum 2009;60: 2124-30. 
42. Grom AA, Hirsch R. T-cell and T-cell receptor abnormalities in the immunopathogenesis of juvenile rheumatoid arthritis. Curr Opin Rheumatol 2000;12:420-4.

43. Frosch M, Roth J. New insights in systemic juvenile idiopathic arthritis--from pathophysiology to treatment. Rheumatology 2008;47:121-5.

44. Chen CY, Tsao CH, Ou LS, Yang MH, Kuo ML, Huang JL. Comparison of soluble adhesion molecules in juvenile idiopathic arthritis between the active and remission stages. Ann Rheum Dis 2002;61:167-70.

45. Frosch M, Metze D, Foell D, Vogl T, Sorg C, Sunderkotter C, Roth J. Early activation of cutaneous vessels and epithelial cells is characteristic of acute systemic onset juvenile idiopathic arthritis. Exp Dermatol 2005;14:259-65.

46. Huang JL, Kuo ML, Hung IJ, Wu CJ, Ou LH, Cheng JH. Lowered IL-4-producing T cells and decreased IL-4 secretion in peripheral blood from subjects with juvenile rheumatoid arthritis. Chang Gung Med J 2001;24:77-83.

47. McInnes IB, Schett G. Cytokines in the pathogenesis of rheumatoid arthritis. Nat Rev Immunol 2007;7:429-42.

48. Ou LS, See LC, Wu CJ, Kao CC, Lin YL, Huang JL. Association between serum inflammatory cytokines and disease activity in juvenile idiopathic arthritis. Clin Rheumatol 2002;21:52-6.

49. Sedlackova L, Velek J, Vavrincova P, Hromadnikova I. Peripheral blood mononuclear cell responses to heat shock proteins and their derived synthetic peptides in juvenile idiopathic arthritis patients. Inflamm Res 2006;55:153-9.

50. De Benedetti F, Meazza C, Oliveri M, Pignatti P, Vivarelli M, Alonzi T, Fattori E, Garrone S, Barreca A, Martini A. Effect of IL-6 on IGF binding protein-3: a study in IL-6 transgenic mice and in patients with systemic juvenile idiopathic arthritis. Endocrinology 2001;142:4818-26.

51. Nguyen TT, Gehrmann M, Zlacka D, Sosna A, Vavrincova P, Multhoff G, Hromadnikova I. Heat shock protein 70 membrane expression on fibroblast-like synovial cells derived from synovial tissue of patients with rheumatoid and juvenile idiopathic arthritis. Scand J Rheumatol 2006;35:447-53.

52. Wu CT, Ou LS, Yeh KW, Lee WI, Huang JL. Serum heat shock protein 60 can predict remission of flare-up in juvenile idiopathic arthritis. Clin Rheumatol 2011;30:959-65.

53. Murray KJ, Luyrink L, Grom AA, Passo MH, Emery H, Witte D, Glass DN. Immunohistological characteristics of $\mathrm{T}$ cell infiltrates in different forms of childhood onset chronic arthritis. J Rheumatol 1996;23:2116-24.

54. Wedderburn LR, Patel A, Varsani H, Woo P. Divergence in the degree of clonal expansions in inflammatory $\mathrm{T}$ cell subpopulations mirrors HLA-associated risk alleles in genetically and clinically distinct subtypes of childhood arthritis. Int Immunol 2001;13:1541-50.

55. Thompson SD, Murray KJ, Grom AA, Passo MH, Choi E, Glass DN. Comparative sequence analysis of the human $\mathrm{T}$ cell receptor beta chain in juvenile rheumatoid arthritis and juvenile spondylarthropathies: evidence for antigenic selection of $\mathrm{T}$ cells in the synovium. Arthritis Rheum 1998;41:482-97.

56. Yao TC, Kuo ML, See LC, Ou LS, Lee WI, Chan CK, Huang JL. RANTES and monocyte chemoattractant protein 1 as sensitive markers of disease activity in patients with juvenile rheumatoid arthritis: a six-year longitudinal study. Arthritis Rheum 2006;54:2585-93.

57. Yao TC, Tsai YC, Huang JL. Association of RANTES promoter polymorphism with juvenile rheumatoid arthritis. Arthritis Rheum 2009;60:1173-8.

58. Gattorno M, Prigione I, Morandi F, Gregorio A, Chiesa S, Ferlito F, Favre A, Uccelli A, Gambini C, Martini A, Pistoia V. Phenotypic and functional characterisation of CCR7+ and CCR7- CD4+ memory T cells homing to the joints in juvenile idiopathic arthritis. Arthritis Res Ther 2005;7:R256-67.

59. Wedderburn LR, Robinson N, Patel A, Varsani H, Woo P. Selective recruitment of polarized $\mathrm{T}$ cells expressing CCR5 and CXCR3 to the inflamed joints of children with juvenile idiopathic arthritis. Arthritis Rheum 2000;43: 765-74.

60. Thompson SD, Luyrink LK, Graham TB, Tsoras M, Ryan M, Passo MH, Glass DN. Chemokine receptor CCR4 on CD4+ $\mathrm{T}$ cells in juvenile rheumatoid arthritis synovial fluid defines a subset of cells with increased IL-4:IFNgamma mRNA ratios. J Immunol 2001;166:6899-906.

61. Lubberts E, Koenders MI, van den Berg WB. The role of T-cell interleukin-17 in conducting destructive arthritis: lessons from animal models. Arthritis Res Ther 2005;7: 29-37.

62. Agarwal S, Misra R, Aggarwal A. Interleukin 17 levels are increased in juvenile idiopathic arthritis synovial fluid and induce synovial fibroblasts to produce proinflammatory cytokines and matrix metalloproteinases. J Rheumatol 2008;35:515-9.

63. Manoury-Schwartz B, Chiocchia G, Bessis N, AbehsiraAmar O, Batteux F, Muller S, Huang S, Boissier MC, Fournier C. High susceptibility to collagen-induced arthritis in mice lacking IFN-gamma receptors. J Immunol 1997;158:5501-6.

64. Vermeire K, Heremans H, Vandeputte M, Huang S, Billiau A, Matthys P. Accelerated collagen-induced arthritis in IFN-gamma receptor-deficient mice. J Immunol 1997;158:5507-13.

65. Murphy CA, Langrish CL, Chen Y, Blumenschein W, McClanahan T, Kastelein RA, Sedgwick JD, Cua DJ. Divergent pro- and antiinflammatory roles for IL-23 and IL-12 in joint autoimmune inflammation. J Exp Med 2003;198:1951-7.

66. Annunziato F, Cosmi L, Liotta F, Maggi E, Romagnani S. Type $17 \mathrm{~T}$ helper cells-origins, features and possible roles in rheumatic disease. Nat Rev Rheumatol 2009;5:325-31.

67. Chen Z, O'Shea JJ. Th17 cells: a new fate for differentiat- 
ing helper T cells. Immunol Res 2008;41:87-102.

68. Mangge H, Kenzian H, Gallistl S, Neuwirth G, Liebmann P, Kaulfersch W, Beaufort F, Muntean W, Schauenstein K. Serum cytokines in juvenile rheumatoid arthritis. Correlation with conventional inflammation parameters and clinical subtypes. Arthritis Rheum 1995;38:211-20.

69. Weaver CT, Hatton RD, Mangan PR, Harrington LE. IL17 family cytokines and the expanding diversity of effector T cell lineages. Annu Rev Immunol 2007;25:821-52.

70. Steinman L. A brief history of $\mathrm{T}(\mathrm{H}) 17$, the first major revision in the $\mathrm{T}(\mathrm{H}) 1 / \mathrm{T}(\mathrm{H}) 2$ hypothesis of $\mathrm{T}$ cell-mediated tissue damage. Nat Med 2007;13:139-45.

71. Foell D, Wittkowski H, Roth J. Mechanisms of disease: a 'DAMP' view of inflammatory arthritis. Nat Clin Pract Rheumatol 2007;3:382-90.

72. Foell D, Wittkowski H, Hammerschmidt I, Wulffraat N, Schmeling H, Frosch M, Horneff G, Kuis W, Sorg C, Roth J. Monitoring neutrophil activation in juvenile rheumatoid arthritis by S100A12 serum concentrations. Arthritis Rheum 2004;50:1286-95.

73. Wittkowski H, Sturrock A, van Zoelen MA, Viemann D, van der Poll T, Hoidal JR, Roth J, Foell D. Neutrophilderived S100A12 in acute lung injury and respiratory distress syndrome. Crit Care Med 2007;35:1369-75.

74. Wittkowski H, Frosch M, Wulffraat N, Goldbach-Mansky R, Kallinich T, Kuemmerle-Deschner J, Fruhwald MC, Dassmann S, Pham TH, Roth J, Foell D. S100A12 is a novel molecular marker differentiating systemic-onset juvenile idiopathic arthritis from other causes of fever of unknown origin. Arthritis Rheum 2008;58:3924-31.

75. Foell D, Wittkowski H, Vogl T, Roth J. S100 proteins expressed in phagocytes: a novel group of damage-associated molecular pattern molecules. J Leukoc Biol 2007;81:28-37.

76. Hofmann MA, Drury S, Fu C, Qu W, Taguchi A, Lu Y, Avila C, Kambham N, Bierhaus A, Nawroth P, Neurath MF, Slattery T, Beach D, McClary J, Nagashima M, Morser J, Stern D, Schmidt AM. RAGE mediates a novel proinflammatory axis: a central cell surface receptor for S100/calgranulin polypeptides. Cell 1999;97:889-901.

77. Schulze zur Wiesch A, Foell D, Frosch M, Vogl T, Sorg C, Roth J. Myeloid related proteins MRP8/MRP14 may predict disease flares in juvenile idiopathic arthritis. Clin Exp Rheumatol 2004;22:368-73.

78. Hoffman HM, Mueller JL, Broide DH, Wanderer AA, Kolodner RD. Mutation of a new gene encoding a putative pyrin-like protein causes familial cold autoinflammatory syndrome and Muckle-Wells syndrome. Nat Genet 2001;29:301-5.

79. Tschopp J, Martinon F, Burns K. NALPs: a novel protein family involved in inflammation. Nat Rev Mol Cell Biol 2003;4:95-104.

80. Zulian F, Martini G, Gobber D, Agosto C, Gigante C, Zacchello F. Comparison of intra-articular triamcinolone hexacetonide and triamcinolone acetonide in oligoarticu- lar juvenile idiopathic arthritis. Rheumatology 2003;42: 1254-9.

81. Eberhard BA, Sison MC, Gottlieb BS, Ilowite NT. Comparison of the intraarticular effectiveness of triamcinolone hexacetonide and triamcinolone acetonide in treatment of juvenile rheumatoid arthritis. J Rheumatol 2004;31:2507-12.

82. Baca V, Lavalle C, Garcia R, Catalan T, Sauceda JM, Sanchez G, Martinez I, Ramirez ML, Marquez LM, Rojas JC. Favorable response to intravenous methylprednisolone and cyclophosphamide in children with severe neuropsychiatric lupus. J Rheumatol 1999;26:432-9.

83. Lovell DJ, Giannini EH, Reiff A, Cawkwell GD, Silverman ED, Nocton JJ, Stein LD, Gedalia A, Ilowite NT, Wallace CA, Whitmore J, Finck BK. Etanercept in children with polyarticular juvenile rheumatoid arthritis. Pediatric Rheumatology Collaborative Study Group. N Engl J Med 2000;342:763-9.

84. Nielsen S, Ruperto N, Gerloni V, Simonini G, Cortis E, Lepore L, Alpigiani MG, Zulian F, Corona F, Alessio M, Barcellona R, Gallizzi R, Rossi F, Magni-Manzoni S, Lombardini G, Filocamo G, Raschetti R, Martini A, Ravelli A. Preliminary evidence that etanercept may reduce radiographic progression in juvenile idiopathic arthritis. Clin Exp Rheumatol 2008;26:688-92.

85. Billiau AD, Loop M, Le PQ, Berthet F, Philippet P, Kasran A, Wouters CH. Etanercept improves linear growth and bone mass acquisition in MTX-resistant polyarticular-course juvenile idiopathic arthritis. Rheumatology 2010;49:1550-8.

86. Prince FH, Twilt M, ten Cate R, van Rossum MA, Armbrust W, Hoppenreijs EP, van Santen-Hoeufft M, Koopman-Keemink Y, Wulffraat NM, van SuijlekomSmit LW. Long-term follow-up on effectiveness and safety of etanercept in juvenile idiopathic arthritis: the Dutch national register. Ann Rheum Dis 2009;68:635-41.

87. Lovell DJ, Reiff A, Ilowite NT, Wallace CA, Chon Y, Lin SL, Baumgartner SW, Giannini EH. Safety and efficacy of up to eight years of continuous etanercept therapy in patients with juvenile rheumatoid arthritis. Arthritis Rheum 2008;58:1496-504.

88. Ruperto N, Lovell DJ, Cuttica R, Wilkinson N, Woo P, Espada G, Wouters C, Silverman ED, Balogh Z, Henrickson M, Apaz MT, Baildam E, Fasth A, Gerloni V, Lahdenne P, Prieur AM, Ravelli A, Saurenmann RK, Gamir ML, Wulffraat N, Marodi L, Petty RE, Joos R, Zulian F, McCurdy D, Myones BL, Nagy K, Reuman P, Szer I, Travers S, Beutler A, Keenan G, Clark J, Visvanathan S, Fasanmade A, Raychaudhuri A, Mendelsohn A, Martini A, Giannini EH. A randomized, placebo-controlled trial of infliximab plus methotrexate for the treatment of polyarticular-course juvenile rheumatoid arthritis. Arthritis Rheum 2007;56:3096-106.

89. van der Laken CJ, Voskuyl AE, Roos JC, Stigter van Walsum M, de Groot ER, Wolbink G, Dijkmans BA, 
Aarden LA. Imaging and serum analysis of immune complex formation of radiolabelled infliximab and anti-infliximab in responders and non-responders to therapy for rheumatoid arthritis. Ann Rheum Dis 2007;66:253-6.

90. Lovell DJ, Ruperto N, Goodman S, Reiff A, Jung L, Jarosova K, Nemcova D, Mouy R, Sandborg C, Bohnsack J, Elewaut D, Foeldvari I, Gerloni V, Rovensky J, Minden K, Vehe RK, Weiner LW, Horneff G, Huppertz HI, Olson NY, Medich JR, Carcereri-De-Prati R, McIlraith MJ, Giannini EH, Martini A. Adalimumab with or without methotrexate in juvenile rheumatoid arthritis. N Engl J Med 2008;359:810-20.

91. Pascual V, Allantaz F, Arce E, Punaro M, Banchereau J. Role of interleukin-1 (IL-1) in the pathogenesis of systemic onset juvenile idiopathic arthritis and clinical response to IL-1 blockade. J Exp Med 2005;201:1479-86.

92. Cazzola M, Ponchio L, de Benedetti F, Ravelli A, Rosti V, Beguin Y, Invernizzi R, Barosi G, Martini A. Defective iron supply for erythropoiesis and adequate endogenous erythropoietin production in the anemia associated with systemic-onset juvenile chronic arthritis. Blood 1996;87: 4824-30.

93. Verbsky JW, White AJ. Effective use of the recombinant interleukin 1 receptor antagonist anakinra in therapy resistant systemic onset juvenile rheumatoid arthritis. J Rheumatol 2004;31:2071-5.

94. Lequerre T, Quartier P, Rosellini D, Alaoui F, De Bandt M, Mejjad O, Kone-Paut I, Michel M, Dernis E, Khellaf M, Limal N, Job-Deslandre C, Fautrel B, Le Loet X, Sibilia J. Interleukin-1 receptor antagonist (anakinra) treatment in patients with systemic-onset juvenile idiopathic arthritis or adult onset Still disease: preliminary experience in France. Ann Rheum Dis 2008;67:302-8.

95. Woo P. Anakinra treatment for systemic juvenile idiopathic arthritis and adult onset Still disease. Ann Rheum Dis 2008;67:281-2.

96. Gattorno M, Piccini A, Lasiglie D, Tassi S, Brisca G, Carta S, Delfino L, Ferlito F, Pelagatti MA, Caroli F, Buoncompagni A, Viola S, Loy A, Sironi M, Vecchi A, Ravelli A, Martini A, Rubartelli A. The pattern of response to anti-interleukin-1 treatment distinguishes two subsets of patients with systemic-onset juvenile idiopathic arthritis. Arthritis Rheum 2008;58:1505-15.

97. Goldbach-Mansky R, Shroff SD, Wilson M, Snyder C, Plehn S, Barham B, Pham TH, Pucino F, Wesley RA, Papadopoulos JH, Weinstein SP, Mellis SJ, Kastner DL. A pilot study to evaluate the safety and efficacy of the longacting interleukin-1 inhibitor rilonacept (interleukin-1
Trap) in patients with familial cold autoinflammatory syndrome. Arthritis Rheum 2008;58:2432-42.

98. Sho M, Yamada A, Najafian N, Salama AD, Harada H, Sandner SE, Sanchez-Fueyo A, Zheng XX, Strom TB, Sayegh MH. Physiological mechanisms of regulating alloimmunity: cytokines, CTLA-4, CD25+ cells, and the alloreactive T cell clone size. J Immunol 2002;169:374451.

99. Ruperto N, Lovell DJ, Quartier P, Paz E, Rubio-Perez N, Silva CA, Abud-Mendoza C, Burgos-Vargas R, Gerloni V, Melo-Gomes JA, Saad-Magalhaes C, Sztajnbok F, Goldenstein-Schainberg C, Scheinberg M, Penades IC, Fischbach M, Orozco J, Hashkes PJ, Hom C, Jung L, Lepore L, Oliveira S, Wallace CA, Sigal LH, Block AJ, Covucci A, Martini A, Giannini EH. Abatacept in children with juvenile idiopathic arthritis: a randomised, double-blind, placebo-controlled withdrawal trial. Lancet 2008;372:383-91.

100. Emery P, Fleischmann R, Filipowicz-Sosnowska A, Schechtman J, Szczepanski L, Kavanaugh A, Racewicz AJ, van Vollenhoven RF, Li NF, Agarwal S, Hessey EW, Shaw TM. The efficacy and safety of rituximab in patients with active rheumatoid arthritis despite methotrexate treatment: results of a phase IIB randomized, double-blind, placebo-controlled, dose-ranging trial. Arthritis Rheum 2006;54:1390-400.

101. El-Hallak M, Binstadt BA, Leichtner AM, Bennett CM, Neufeld EJ, Fuhlbrigge RC, Zurakowski D, Sundel RP. Clinical effects and safety of rituximab for treatment of refractory pediatric autoimmune diseases. J Pediatr 2007;150:376-82.

102. Kuek A, Hazleman BL, Gaston JH, Ostor AJ. Successful treatment of refractory polyarticular juvenile idiopathic arthritis with rituximab. Rheumatology 2006;45:1448-9.

103. Yokota S, Imagawa T, Mori M, Miyamae T, Aihara Y, Takei S, Iwata N, Umebayashi H, Murata T, Miyoshi M, Tomiita M, Nishimoto N, Kishimoto T. Efficacy and safety of tocilizumab in patients with systemic-onset juvenile idiopathic arthritis: a randomised, double-blind, placebo-controlled, withdrawal phase III trial. Lancet 2008;371:998-1006.

104. Brough R, Cleary G. When does a knee "need" a "joint" assessment? Arch Dis Child Educ Pract Ed 2007;92:ep44-9.

105. Strand V, Kimberly R, Isaacs JD. Biologic therapies in rheumatology: lessons learned, future directions. Nat Rev Drug Discov 2007;6:75-92. 


\title{
兒童特異性關節炎的新進展
}

\author{
黄璟隆
}

兒童特異性關節炎包含各式原因未明的慢性關節炎的疾病, 屬兒科最常見的風濕性疾患 且常合併各種併發症。最近幾年, 有關兒童特異性關節炎的病因、疾病控制與否的定義及用 來治療關節炎的生物製劑, 其發展有很大的進展。兒童特異性關節炎發病原因與基因遺傳及 環境都有關; 其中包括周產期發生的因素、病毒或細菌感染、表觀遺傳學及營養不正常皆有 關係。在本文中亦探討此病與發炎細胞素免疫反應的網路路徑, 另外, 亦描述新近發展生物 製劑用於此病的現況。雖然生物製劑的使用對改善䍜患特異性關節炎的兒童有很大的改善, 但長期的副作用及預後，仍需更多時間的觀察。(長庚醫誌 2012;35:1-14)

關鍵詞：兒童特異性關節炎, 病因, 生物製劑

長庚醫療財團法人林口長庚紀念醫院 兒童內科部 兒童過敏氣喘風濕科 ; 長庚大學 醫學院 受文日期：民國100年4月13日；接受刊載：民國100年8月12日

通訊作者: 黄璟隆教授, 長庚醫療財團法人林口長庚紀念醫院 兒童內科部 兒童過敏氣喘風濕科。桃園縣333龜山鄉復興 街5號。Tel: (03)3281200轉8206; Fax: (03)3294843; E-mail: long@cgmh.org.tw 